\title{
BIOLOGÍA REPRODUCTIVA DE LA TACUARITA AZUL POLIOPTILA DUMICOLA EN LA RESERVA DE LA ESCUELA GRANJA (UNL), ESPERANZA, SANTA FE, ARGENTINA
}

\author{
De la Peña, M. R. ${ }^{1}$
}

\section{RESUMEN}

Se realizan aportes sobre la biología reproductiva de Polioptila dumicola básicamente en la crianza de los pichones, alimentación y cuidados de los juveniles.

El estudio se realizó en un sector de monte de 35 hectáreas dentro de la Reserva de la Escuela Granja. Se detallan las fechas de localización de los nidos, árboles utilizados para ubicarlos, altura desde el suelo y contenido de los mismos.

En los años 1998 y 2001, se determinó la densidad poblacional en casos de nidificación simultánea. Se documentó la distancia entre los nidos y se realizó el seguimiento hasta que los pichones abandoman el nido. En los dos años se ubicaron 23 nidos en esa condición.

Palabras clave: Polioptila dumicola, reproducción, pichones, nidificación simultánea, Esperanza, Santa Fe.

\section{SUMMARY}

\section{Reproductive biology of tacuarita azul Polioptila dumicola in the farm school of Esperanza (UNL) Santa Fe, Argentina.}

New contributions to the reproductive biology of the Masked Gnatcatcher (Polioptila dumicola) are presented, mainly description and breeding of the nestlings. In 1998 and 2001, population density in cases of simultaneous nesting was determined. In both years 23 nest holding these conditions were identifiled. Vegetal suppot preferred by the species was also taken into account, and the mean number of nest by hectare was recorded. Data on the distance between nest, height from the ground, and follow up until the young left the nest were recorded.

Key words: Polioptila dumicola, nestlings, breeding, simultaneous nesting, Esperanza, Santa Fe.

\footnotetext{
1.- Médico Veterinario. Académico Correspondiente, de la Academia Nacional de Agronomía y Veterinaria (Argentina) y Académico Honorario Correspondiente de la Universidad de Pilar (Paraguay). Profesor Honorario de la Universidad Nacional del Litoral.

3 de Febrero 1870. (3080) Esperanza, provincia de Santa Fe. Email: martin@fca.unl.edu.ar Manuscrito recibido el $1^{\circ}$ de abril de 2005 y aceptado para su publicación el 18 de julio de 2005 .
} 